\title{
The Contribution of Immune Evasive Mechanisms to Parasite Persistence in Visceral Leishmaniasis
}

\author{
Elisangela Oliveira de Freitas ${ }^{1}$, Fabiana Maria de Souza Leoratti ${ }^{1}$, \\ Célio Geraldo Freire-de-Lima ${ }^{2}$, Alexandre Morrot ${ }^{3 * t}$ and Daniel Ferreira Feijó ${ }^{4 * t}$ \\ ${ }^{1}$ The Jenner Institute, University of Oxford, Oxford, UK, ${ }^{2}$ Instituto de Biofísica Carlos Chagas Filho, Universidade Federal do \\ Rio de Janeiro, Rio de Janeiro, Brazil, ${ }^{3}$ Laboratorio de Biologia do Sistema Imune, Departmento de Imunologia, Instituto de \\ Microbiologia, Universidade Federal do Rio de Janeiro, Rio de Janeiro, Brazil, ${ }^{4}$ Laboratório Integrado de Microbiologia e \\ Imunoregulação, Centro de Pesquisas Gonçalo Moniz, Fundação Oswaldo Cruz (FIOCRUZ), Salvador, Brazil
}

\section{OPEN ACCESS}

Edited by: Amy Rasley,

Lawrence Livermore National Laboratory, USA

Reviewed by:

Hira Nakhasi,

U.S. Food and Drug

Administration, USA Julio Aliberti,

Cincinnati Children's

Hospital Medical Center, USA

*Correspondence:

Alexandre Morrot morrot@micro.ufri.br;

Daniel Ferreira Feijó

danielffeijo@gmail.com

${ }^{\dagger}$ Alexandre Morrot and Daniel

Ferreira Feijó contributed

equally to this review.

Specialty section:

This article was submitted to Microbial Immunology,

a section of the journal

Frontiers in Immunology

Received: 11 January 2016

Accepted: 08 April 2016

Published: 22 April 2016

Citation:

Freitas EO, Leoratti FMS, Freire-de-Lima CG, Morrot A and Feijo DF (2016) The Contribution of

Immune Evasive Mechanisms

to Parasite Persistence

in Visceral Leishmaniasis.

Front. Immunol. 7:153.

doi: 10.3389/fimmu.2016.00153
Leishmania is a genus of protozoan parasites that give rise to a range of diseases called Leishmaniasis that affects annually an estimated 1.3 million people from 88 countries. Leishmania donovani and Leishmania (L.) infantum chagasi are responsible to cause the visceral leishmaniasis. The parasite can use assorted strategies to interfere with the host homeostasis to establish persistent infections that without treatment can be lethal. In this review, we highlight the mechanisms involved in the parasite subversion of the host protective immune response and how alterations of host tissue physiology and vascular remodeling during VL could affect the organ-specific immunity against Leishmania parasites.

Keywords: leishmaniasis, treatment, Leishmania donovani, host protective responses, immune evasive mechanisms

\section{INTRODUCTION}

Leishmaniasis is a complex of mammalian neglected tropical diseases, caused by over 20 different parasitic protozoans of genera Leishmania. Transmission can occur as zoonotically or anthroponotically, usually by the bite of female by $\sim 30$ different species phlebotomine sandflies (1). Three main manifestations can occur that include the cutaneous (CL), mucocutaneous affecting the skin and mucous membranes, and visceral leishmaniasis (VL) (1).

These diseases are endemics in 98 countries, and around 350 million people are at risk. The estimate of annual new cases is around two million (2). VL is a disease that is fatal if untreated; around 500,000 new cases are estimated and 50,000 deaths reported annually (3). The disease is caused by Leishmania donovani complex in East Africa and the Indian subcontinent and Leishmania infantum in Europe, North Africa, and Latin America (4).

Two different types of VL can occur, which differ in the way of transmission: the zoonotic VL that is transmitted from animal to vector to human and the anthtoponotic VL where transmission from human to vector to human. So, humans are an occasional host and animals, especially dogs, play the role of reservoir of the parasite. In areas of $L$. infantum, the zoonotic VL is found, while in areas of L. donovani transmission, anthroponotic VL is found (5).

Visceral leishmaniasis is also known as kala-azar and is characterized by irregular fever, anemia, hepatosplenomegaly, pancytopenia, weight loss, and hypergammaglobulinemia. It is widely confined to East Africa, Indian subcontinent, Brazil, and regions bordering the Mediterranean. Dermal 
leishmanoid (PKDL) is a macular, maculo-papular, or nodular rash representing a complication of VL that is usually noted after treatment in Sudan and less often in other East African countries and in the Indian Subcontinent. This often affects immunosuppressed individuals in L. infantum endemic areas (6). These lesions can appear anywhere on the body, but most commonly occur on the face (7). The interval between treated VL and PKDL is 0-6 months in Sudan and between 6 months to 3 years in India. As the nodular lesions contain many parasites (8), and such cases are the putative reservoir for anthroponotic VL between epidemic cycles, this form of disease is more infectious (6).

Fortreatmentofleishmaniasisfewdrugsareavailableatmoment. They include: pentavalent antimonium [Sodium atibogluconate $\left(\right.$ Pentostam $\left.{ }^{\circledR}\right)$ ] and meglumine antimoniate $\left(\right.$ Glucantime ${ }^{\circledR}$ ), pentamidine, amphotericin B, liposomal amphotericin B, miltefosine, and paramomycin $(9,10)$. These face limitations for actual treatment, in that most of them require hospitalization that increases the cost, and they are highly toxic (9).

The mechanism of resistance to pentavalent antimonials is the focus of much research; they have been the standard drugs despite their high toxicity (7). Those drugs are not in use now in Bihar State, India, because of the high rate of drug resistance, where more than $65 \%$ of previously untreated patients fail to respond or readily relapse. Sodium stibogluconate (Pentostam ${ }^{\circledR}$ ) and meglumine antimoniate (Glucantime ${ }^{\circledR}$ ) are still in use elsewhere. Administration is intravenous or intramuscular, and they show the some efficacy when used in equipollent doses (7).

Fatigue, body aches, electrocardiographic abnormalities, raised aminotransferase levels, and chemical pancreatitis are frequently reported secondary effects. Fatal pancreatitis has been reported in patients with VL and HIV infection (11). AmBisome, a liposome formulation of amphotericin $\mathrm{B}$, is the current standard treatment for VL, particularly against L. donovani in Bihar, and just one dose treatment was efficient in the treatment in rural public hospitals in Bangladesh (2). The effectiveness of treatment was less against $L$. donovani in East Africa and L. infantum in Latin America. The situation was not different when the treatment was with paromomycin that was efficient in the Indian subcontinent but did not work in East Africa (7).

The mechanisms of parasite evasion in VL are not only caused by down modulation of host protective immune response directly. Several reports showed that tissue physiological and vascular remodeling alterations caused by the disease also contribute to parasite replication and persistence. In this review, we discuss: (1) how the parasite subvert the host immune system by infecting specific keys cells and (2) how changes in the tissue structure and physiology could affect organ-specific immunity during VL.

Following the deposition of infective metacyclic promastigotes into the dermis, the skin innate immune system detects invading promastigotes, recruits inflammatory cells to sites of invasion within minutes, and promotes the induction of adaptive immunity (12). Initial sensing of the parasite involves pattern recognition receptors. The host skin immune system initially senses the parasite through pattern recognition receptors and complement receptors present on different cell types including neutrophils, macrophages, dendritic cells (DCs), and natural killer (NK) cells. Several Toll-like receptors (TLRs) such as TLR2,
TLR3 (13), TLR4 (14), TLR7 (15), and TLR9 (14) have been shown to contribute to innate sensing and recognition of Leishmania by various innate immune cells. This recognition leads to activation of intracellular signaling pathways that are necessary for the initiation of inflammatory responses and control of parasite proliferation by the innate immune response (16).

Neutrophils are essential cells involved in inflammatory response and contribute to phagocytosis and killing of microbial pathogens. However, the precise role of these cells in VL remains to be addressed. McFarlane et al. (17) demonstrated that neutrophil depletion at the beginning of $L$. donovani infection leads to increase in parasite burden in the spleen and bone marrow but not in the liver, enhanced splenomegaly, a delay in the maturation of hepatic granulomas, a decrease in inducible nitric oxide synthase (iNOS) expression within granulomas, and increased levels of IL-4 and IL-10 with significant increase in the ratio of L. donovani-specific serum IgG1/IgG2a levels (17).

Although promastigotes are capable of directly invading DCs and macrophages following their deposition by infected sandflies, several TLRs have been shown to contribute to this process and play a vital role in the production of proinflammatory cytokines that are critical for immunity (18). Also activation of inflammasome and production of IL- $1 \beta$ are important for restriction in vivo infection with L. infantum in murine model (19). Polymorphisms within the human $I L 1 B$ gene are associated with clinical severity of the disease (20).

Experimental studies in mice suggest that the control of VL may be associated with the development of parasite-specific, cell-mediated immune responses involving both $\mathrm{CD}^{+}$and $\mathrm{CD} 8^{+}$ T cells (21). These cells produce IFN- $\gamma$, which activates infected macrophages, leading to the production of $\mathrm{NO}$ and other free radicals that kill the parasites. DCs activate $\mathrm{CD} 8^{+} \mathrm{T}$ cells through mechanisms that involve antigen cross presentation (22). Also, IL-17 producing $\gamma \delta \mathrm{T}$ cells suppress early control of parasite growth in the liver, and inflammatory monocytes were an important target for the suppressive effects of IL-17 (23).

In $\mathrm{VL}$, both $\mathrm{CD}^{+}$and $\mathrm{CD}^{+} \mathrm{T}$ cells have been implicated in the resistance and healing capacity against $L$. donovani. The production of IFN- $\gamma$ by helper $\mathrm{CD}^{+} \mathrm{T}$ cells and/or $\mathrm{CD}^{+}$lymphocytes is associated with protection (24). The Th1 and Th17 profile are correlated with infection resolution (25-28) and Th2 response contribute to susceptibility and disease progression (29). High levels of IL-10 are another regulatory cytokine involved immune suppression inducing parasite persistence and chronicity of disease (29). In humans, IL-27 promoted the production of IL-10 and inhibited secretion of IL-17 by CD4 ${ }^{+}$T cells (30). Recently, Ansari et al. (31) showed elevated circulating levels of IL-27 and elevated expression of IL-27p28 and EBI-3 transcripts in VL patients. Owens et al. (32) demonstrated that CD11 $1 c^{\text {hi }}$ DCs promote expansion and maintenance of $\mathrm{T}$ cells inducing the production of IL-10 and IL-27 in vivo.

In infected individuals with active symptoms of VL was observed high levels of IFN- $\gamma$ and IL-10, the main source of IFN$\gamma$ production found in both innate and cellular responses. On the other hand, IL-10 was restricted to $\mathrm{CD}^{+} \mathrm{T}$ and $\mathrm{B}$ cells (33). In splenic aspirate cells from VL patients, anti-IL-10 antibodies promoted killing of parasite and increased the secretion of IFN- $\gamma$ 
and TNF- $\alpha$ in splenic cells ex vivo (34). Recently demonstrated in healed visceral human leishmaniasis patients, $\mathrm{CD} 8^{+} \mathrm{T}$ cells were activated and the granzyme $\mathrm{B}$ levels were found increased when compared to naive group and active VL (35).

Suppression of T cell response is thought to be involved in the pathogenesis of VL. Regulatory T cell (Treg)-mediated immune suppression is reported in animal models of Leishmania infection. IL-10 receptor blockade mice were resistant to $L$. donovani infection (36). Also, low levels expression of CD40 in DC induced severity to infection by activation of Treg and the production of IL-10 (37). In immunocompromised aly/aly mice infected with L. donovani $\mathrm{CD}^{+} \mathrm{Foxp}^{+}$Treg cells were increased in the liver inducing progression of granuloma formation (38). Majumder et al. (14) showed that mice vaccinated with soluble leishmanial antigen (SLA)-pulsed CpG-ODN-stimulated dendritic cells (SLA-CpG-DCs) decreased the number of Treg cells; and consequently, there was low production of TGF- $\beta$. Interestingly,

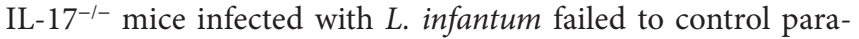
sitemia, increasing the proliferation of Treg cells and production of IL-10 (38). In humans, Treg cells produced high levels of IL-10 indicating immune suppression among VL patients (39). This mechanism will be useful to determine drug treatment and disease prognostic.

Studies investigating the immunoregulatory function, CTLA-4 (CD152 - cytotoxic T lymphocyte antigen-4) has a role regulatory in activation of T cells, including Treg cells $(40,41)$, and PD-1 (programmed cell death-1) is broadly expressed on activated T cells, regulatory $\mathrm{T}$ cells, and other hematopoietic cells (42). Administration of monoclonal antibodies against CTLA-4 reduced the burden of parasite in the liver in VL and increased the frequency of IFN- $\gamma$ and IL-4 producing T cells in the liver (42). Blockade of the PD-1 during L. infantum in dogs, CD8 ${ }^{+}$ and $\mathrm{CD}^{+} \mathrm{T}$ cells recovered functionality and increased reactive oxygen species production of phagocytes (43). Identification of the mechanism of blocking CTLA- 4 or PD-1 reverts the downregulation of $\mathrm{T}$ cell response to infection. Ligand for the inhibitory receptor PD-1 (B7-H1) constitutively expressed in T cells showed interaction between B7-1: CTLA-4 and the PD-L1 (B7-H1): PD-1 pathways (44). The blockade of B7-H1, the ligand for the inhibitory receptor PD-1, was found to increase survival of $\mathrm{CD}^{+} \mathrm{T}$ cells and induce protective immunity (45). Recently, HIV-1-coinfected patients with VL Treg cells expressed high levels of CTLA-4, showing impaired immunologic profile explaining persistence and/or relapse of the disease (46).

\section{LIVER, BONE MARROW, AND SPLEEN: THREE ORGANS, DIFFERENT IMMUNE RESPONSES}

One of the hallmarks of VL is hepatosplenomegaly $(1,21,22,47)$. There is a fine line between immune responses that effectively control parasite growth and induce long-term immunity and those that allow parasite persistence and associated disease (29). Thus, differences in splenic and hepatic tissue microenvironments dictate differences in the ability to generate effective immune responses and parasite control in these organs.
The liver is one of the primary target organs in VL. In experimental models of $\mathrm{VL}$, infection in the liver is self-resolving within 2-3 months (22). This resolution of disease is associated with the development of granuloma formation mediated by a Th1 immune response both in humans and dogs as well (48-50). The development of inflammatory granulomas around infected liver macrophages leading to immunity is a T-cell-driven event. This Th1-dominated response is mediated by TLR7, TLR8, TLR9, IL-1, and IL-18 via the MyD88 signaling pathway (15). An efficient granuloma formation involves the expression of inducible iNOS by macrophages $(22,51)$, which is regulated by several pro-inflammatory (Th1) cytokines, such as IL-12, IFN- $\gamma$, TNF- $\alpha$, lymphotoxin, granulocyte/macrophage colony-stimulating factor, IL-2 $(52,53)$ as well as intact and functional NK and NKT cells (54-56).

Leishmania parasites have developed strategies to evade the host immune defenses: invasion of cell types to modulate cell host function to replicate and to downregulate the host immunity for its persistence (24). In a murine model of $L$. donovani infection, liver-resident macrophages (Kupffer cells) infected have a different trancriptomic network profile compared to uninfected Kupffer cells isolated from the same mouse (57). Retinoid X receptor alpha $(\mathrm{RXR} \alpha)$ was identified as a key hub within this network, and its pharmacological pertubation with agonists of RXR $\alpha$ enhanced the innate resistance of Kupffer cells to Leishmania infection in vivo (57). Also Hepatic stellate cells infected in vitro and in vivo with $L$. donovani produces immunoregulatory cytokines that induces $\mathrm{CD}^{+}{ }^{+} \mathrm{T}$ cells to become Treg that leads to parasite persitence (58).

Although initially unaffected (due to efficient local immune response), the liver is slowly damaged as the disease progresses (59). Consequently, VL leads to hepatic dysfunction, such as coagulation defects, increased serum concentrations of several liver-specific enzymes, and changes in the cholesterol biosynthesis $(60,61)$. The liver is the main source of cholesterol biosynthesis in mammals (62) and the decreased serum cholesterol was associated with VL severity and parasite persitence $(63,64)$. Ghosh et al. (65) identify that the L. donovani infection downregulates miR122 in hepatic tissue, lowering serum cholesterol and increasing parasite burden. The pathology is reversed when hepatic levels of miR-122 are restored with increased serum cholesterol and reduction of liver parasite burden.

In VL, the spleen also becomes chronically infected by mechanisms that are less well understood. In EVL, the spleen becomes enlarged and splenomegaly can account for up to $15 \%$ of the body weight of infected mice in as little as $6-8$ weeks postinfection (22). The persistence of parasites in the spleen is associated with changes in the splenic lymphoid microenvironment, and concomitant increases in the rate of T-cell apoptosis, decreased responsiveness to leishmanial antigens, and drug resistance (21, 22, 66-68).

The spleen is composed by red (RP) and white pulp (WP), separated by an interface called the marginal zone (MZ). The splenic RP contains macrophages that recycle iron blood from aging red blood cells. The WP is organized similarly to a lymph node, containing T-cell and B-cell follicles. It is in the WP where antigen-specific immune responses are generated (69). 
During VL, there is an intense vascular remodeling in the RP and WP $(68,70-72)$. This vascular change causes disruption to both the gp $38^{+}$fibroblastic reticular cell network, which guides $\mathrm{T}$ cell and DC migration to the T cell zone, and the follicular DC network in the B cell follicles $(73,74)$. As a consequence, DCs fails to migrate to $\mathrm{T}$ cell zone, resulting in an diminishes priming of $\mathrm{T}$ cells (73). Dalton et al. (75) showed that by using a receptor tyrosine kinase inhibitor, sunitinib maleate $(\mathrm{Sm})$, vascular remodeling and splenomegaly associated with VL can be blocked, and the pathology can be reversed. The use of Sm alone did not cause a reduction in parasite burden in the spleen; but when combined with conventional antimonial drugs, enhanced leishmanicidal activity with enhanced immune response mediated by $\mathrm{CD} 4^{+}$ T cells producing IFN- $\gamma$ and TNF (75).

Bone marrow is also affected during the chronic phase of VL in both patients and experimental models $(76,77)$. In patients, bone marrow shows moderate to severe megaloblastosis, megakaryocitic hyperplasia, and increased number of plasma cells. All parameters were correlated to parasite load (78). Calvo et al. (79) identified that splenic sequestration and ineffective hematopoiesis appear to be the main etiopathogenetic factors in the bone marrow changes and peripheral cytopenias. This is also observed in experimental models. Lafuse et al. (80) identified increased BFU-E and CFU-E progenitor populations in the spleen and bone marrow and differentially altered erythroid gene expression in these organs. In murine model, there is a correlation in the hematopoietic activity with parasite load in the bone marrow (81). Stromal macrophages are the main target for L. donovani infection in vivo and in vitro; and as a consequence of the selective induction of GM-CSF and TNF- $\alpha$ production, infected stromal macrophages preferentially support increased levels of myelopoiesis (82). Also, Singal and Singh (83) demonstrated that $L$. donovani amastigotes antigen could also induce both in vitro and in vivo myelopoiesis. If this preferential increase of myelopoeisis may merely serve to increase the number of phagocytes, which are the host cells targets for parasite replication, as well as for increasing the phagocytic uptake of the parasite, further studies are needed to elucidate this question.

\section{CONCLUSION AND PERSPECTIVES}

Despite the global public health importance of leishmaniasis, progress in developing vaccines against the disease has lagged

\section{REFERENCES}

1. Pearson RD, Sousa AQ. Clinical spectrum of Leishmaniasis. Clin Infect Dis (1996) 22(1):1-13. doi:10.1093/clinids/22.1.1

2. WHO. Leishmaniasis. (2015). Available from: http://www.who.int/ leishmaniasis/en/

3. Desjeux P. The increase in risk factors for leishmaniasis worldwide. Trans $R$ Soc Trop Med Hyg (2001) 95(3):239-43. doi:10.1016/ S0035-9203(01)90223-8

4. Lukes J, Mauricio IL, Schonian G, Dujardin JC, Soteriadou K, Dedet JP, et al. Evolutionary and geographical history of the Leishmania donovani complex with a revision of current taxonomy. Proc Natl Acad Sci U S A (2007) 104(22):9375-80. doi:10.1073/pnas.0703678104 because of some key technical hurdles, including the fact that the disease occurs mostly in the world's poorest countries, and the absence of financial incentives to pharmaceutical companies. Chemotherapy for VL has changed little in 50 years; in areas where drug resistance has yet occurred. The conventional drug treatment still involves parenteral administration of antimonial compounds (Pentostam and Glucantime). Amphotericin B, particularly in liposomal formulation (84), has become the drug of choice in developed countries and where antimony resistance is problematic; but issues of cost and toxicity remain. Also, there are already clinical cases of treatment failure related to liposomal amphotericin B $(67,85)$. The onset of immunosuppression is a critical event during the progression of VL in a susceptible population. A more comprehensive study would be very helpful for a better understanding about how morpho-physiological tissue alterations and pathogen factors would affect organ-specific immunity during VL. Recently, the use of Systems Biology has been increased (86). Different in silico approaches are available for identification of interactions between pathogens and hosts and factors for parasite dissemination and disease progression, as well as to the selection of promising antigens as vaccine candidates, since experimental methods are difficult and time consuming (87, 88). A new approach to develop treatment strategy against VL in resistance cases has to take into account not only by the development of new leishmanicidal drugs but also by the drugs that could reverse the anergic immune response and pathophysiological changes during VL, such as hypocholesterolemia and splenic neovascularization. The use of an anti-vascular therapy (with $\mathrm{Sm}$, for instance) could be an alternative choice to splenectomy in cases of failure treatment for lipossomal Amphotericin B $(67,85)$.

\section{AUTHOR CONTRIBUTIONS}

EOF, FML and DFF wrote the paper. DFF and AM made substantial contributions to the conception of the work. CGF-L revised the manuscript.

\section{ACKNOWLEDGMENTS}

This work was supported by grants from Conselho Nacional de Desenvolvimento Científico e Tecnológico do Brasil (CNPq), Fundação de Amparo à Pesquisa do Estado do Rio de Janeiro (FAPERJ). We would also like to thank Mrs. Deana Braden for English review and language editing of the manuscript.

5. Alvar J, Velez ID, Bern C, Herrero M, Desjeux P, Cano J, et al. Leishmaniasis worldwide and global estimates of its incidence. PLoS One (2012) 7(5):e35671. doi:10.1371/journal.pone.0035671

6. Chappuis F, Sundar S, Hailu A, Ghalib H, Rijal S, Peeling RW, et al. Visceral leishmaniasis: what are the needs for diagnosis, treatment and control? Nat Rev Microbiol (2007) 5(11):873-82. doi:10.1038/nrmicro1748

7. Barrett MP, Croft SL. Management of trypanosomiasis and leishmaniasis. Br Med Bull (2012) 104:175-96. doi:10.1093/bmb/lds031

8. Addy M, Nandy A. Ten years of kala-azar in west Bengal, Part I. Did post-kala-azar dermal leishmaniasis initiate the outbreak in 24-Parganas? Bull World Health Organ (1992) 70(3):341-6.

9. Maltezou HC. Drug resistance in visceral leishmaniasis. J Biomed Biotechnol (2010) 2010:617521. doi:10.1155/2010/617521 
10. Sundar S, Chakravarty J. Leishmaniasis: an update of current pharmacotherapy. Expert Opin Pharmacother (2013) 14(1):53-63. doi:10.1517/ 14656566.2013.755515

11. Santos J, Rivero A, Marquez M. [Acute pancreatitis with a fatal evolution due to antimonials in patients with visceral leishmaniasis and HIV infection]. An Med Interna (2000) 17(10):562-3.

12. Liu D, Uzonna JE. The early interaction of Leishmania with macrophages and dendritic cells and its influence on the host immune response. Front Cell Infect Microbiol (2012) 2:83. doi:10.3389/fcimb.2012.00083

13. Flandin JF, Chano F, Descoteaux A. RNA interference reveals a role for TLR2 and TLR3 in the recognition of Leishmania donovani promastigotes by interferon-gamma-primed macrophages. Eur J Immunol (2006) 36(2):411-20. doi:10.1002/eji.200535079

14. Majumder S, Bhattacharjee A, Paul Chowdhury B, Bhattacharyya Majumdar S, Majumdar S. Antigen-pulsed CpG-ODN-activated dendritic cells induce host-protective immune response by regulating the $\mathrm{T}$ regulatory cell functioning in Leishmania donovani-infected mice: critical role of CXCL10. Front Immunol (2014) 5:261. doi:10.3389/fimmu.2014.00261

15. Paun A, Bankoti R, Joshi T, Pitha PM, Stager S. Critical role of IRF-5 in the development of $\mathrm{T}$ helper 1 responses to Leishmania donovani infection. PLoS Pathog (2011) 7(1):e1001246. doi:10.1371/journal. ppat. 1001246

16. Faria MS, Reis FC, Lima AP. Toll-like receptors in Leishmania infections: guardians or promoters? J Parasitol Res (2012) 2012:930257. doi:10.1155/2012/930257

17. McFarlane E, Perez C, Charmoy M, Allenbach C, Carter KC, Alexander J, et al. Neutrophils contribute to development of a protective immune response during onset of infection with Leishmania donovani. Infect Immun (2008) 76(2):532-41. doi:10.1128/IAI.01388-07

18. Srivastava A, Singh N, Mishra M, Kumar V, Gour JK, Bajpai S, et al. Identification of TLR inducing Th1-responsive Leishmania donovani amastigote-specific antigens. Mol Cell Biochem (2012) 359(1-2):359-68. doi:10.1007/s11010-011-1029-5

19. Lima-Junior DS, Costa DL, Carregaro V, Cunha LD, Silva AL, Mineo $\mathrm{TW}$, et al. Inflammasome-derived IL-1beta production induces nitric oxide-mediated resistance to Leishmania. Nat Med (2013) 19(7):909-15. doi:10.1038/nm.3221

20. Moravej A, Rasouli M, Kalani M, Asaei S, Kiany S, Najafipour S, et al. IL-1beta $(-511 \mathrm{~T} / \mathrm{C})$ gene polymorphism not IL-1beta $(+3953 \mathrm{~T} / \mathrm{C})$ and LT-alpha $(+252 \mathrm{~A} / \mathrm{G})$ gene variants confers susceptibility to visceral leishmaniasis. Mol Biol Rep (2012) 39(6):6907-14. doi:10.1007/s11033-012-1517-z

21. Goto H, Prianti M. Immunoactivation and immunopathogeny during active visceral leishmaniasis. Rev Inst Med Trop Sao Paulo (2009) 51(5):241-6. doi:10.1590/S0036-46652009000500002

22. Kaye PM, Svensson M, Ato M, Maroof A, Polley R, Stager S, et al. The immunopathology of experimental visceral leishmaniasis. Immunol Rev (2004) 201:239-53. doi:10.1111/j.0105-2896.2004.00188.x

23. Sheel M, Beattie L, Frame TC, de Labastida Rivera F, Faleiro RJ, Bunn PT, et al. IL-17A-producing gammadelta $\mathrm{T}$ cells suppress early control of parasite growth by monocytes in the liver. J Immunol (2015) 195(12):5707-17. doi:10.4049/jimmunol.1501046

24. Kaye P, Scott P. Leishmaniasis: complexity at the host-pathogen interface. Nat Rev Microbiol (2011) 9(8):604-15. doi:10.1038/nrmicro2608

25. Reiner SL, Locksley RM. Cytokines in the differentiation of Th1/Th2 CD4+ subsets in leishmaniasis. JCell Biochem (1993) 53(4):323-8. doi:10.1002/ jcb.240530409

26. Pitta MG, Romano A, Cabantous S, Henri S, Hammad A, Kouriba B, et al. IL-17 and IL-22 are associated with protection against human kala azar caused by Leishmania donovani. J Clin Invest (2009) 119(8):2379-87. doi:10.1172/ JCI38813

27. Sacramento LA, Cunha FQ, de Almeida RP, da Silva JS, Carregaro V. Protective role of 5-lipoxigenase during Leishmania infantum infection is associated with Th17 subset. Biomed Res Int (2014) 2014:264270. doi:10.1155/ 2014/264270

28. Ghosh K, Sharma G, Saha A, Kar S, Das PK, Ukil A. Successful therapy of visceral leishmaniasis with curdlan involves T-helper 17 cytokines. J Infect Dis (2013) 207(6):1016-25. doi:10.1093/infdis/jis771
29. Stanley AC, Engwerda CR. Balancing immunity and pathology in visceral leishmaniasis. Immunol Cell Biol (2007) 85(2):138-47. doi:10.1038/ sj.icb7100011

30. Murugaiyan G, Mittal A, Lopez-Diego R, Maier LM, Anderson DE, Weiner HL. IL-27 is a key regulator of IL-10 and IL-17 production by human CD4+ T cells. J Immunol (2009) 183(4):2435-43. doi:10.4049/ jimmunol.0900568

31. Ansari NA, Kumar R, Gautam S, Nylen S, Singh OP, Sundar S, et al. IL-27 and IL-21 are associated with T cell IL-10 responses in human visceral leishmaniasis. J Immunol (2011) 186(7):3977-85. doi:10.4049/jimmunol.1003588

32. Owens BM, Beattie L, Moore JW, Brown N, Mann JL, Dalton JE, et al. IL-10-producing Th1 cells and disease progression are regulated by distinct CD11c(+) cell populations during visceral leishmaniasis. PLoS Pathog (2012) 8(7):e1002827. doi:10.1371/journal.ppat.1002827

33. Peruhype-Magalhaes V, Martins-Filho OA, Prata A, Silva Lde A, Rabello A, Teixeira-Carvalho A, et al. Mixed inflammatory/regulatory cytokine profile marked by simultaneous raise of interferon-gamma and interleukin-10 and low frequency of tumour necrosis factor-alpha $(+)$ monocytes are hallmarks of active human visceral Leishmaniasis due to Leishmania chagasi infection. Clin Exp Immunol (2006) 146(1):124-32. doi:10.1111/ j.1365-2249.2006.03171.x

34. Gautam S, Kumar R, Maurya R, Nylen S, Ansari N, Rai M, et al. IL-10 neutralization promotes parasite clearance in splenic aspirate cells from patients with visceral leishmaniasis. J Infect Dis (2011) 204(7):1134-7. doi:10.1093/ infdis/jir461

35. Kaushal H, Bras-Goncalves R, Negi NS, Lemesre JL, Papierok G, Salotra P. Role of CD8(+) T cells in protection against Leishmania donovani infection in healed Visceral Leishmaniasis individuals. BMC Infect Dis (2014) 14:653. doi:10.1186/s12879-014-0653-6

36. Murray HW, Lu CM, Mauze S, Freeman S, Moreira AL, Kaplan G, et al. Interleukin-10 (IL-10) in experimental visceral leishmaniasis and IL-10 receptor blockade as immunotherapy. Infect Immun (2002) 70(11):6284-93. doi:10.1128/IAI.70.11.6284-6293.2002

37. Martin S, Agarwal R, Murugaiyan G, Saha B. CD40 expression levels modulate regulatory $\mathrm{T}$ cells in Leishmania donovani infection. J Immunol (2010) 185(1):551-9. doi:10.4049/jimmunol.0902206

38. Tiwananthagorn S, Iwabuchi K, Ato M, Sakurai T, Kato H, Katakura K. Involvement of $\mathrm{CD} 4(+)$ Foxp3(+) regulatory $\mathrm{T}$ cells in persistence of Leishmania donovani in the liver of alymphoplastic aly/aly mice. PLoS Negl Trop Dis (2012) 6(8):e1798. doi:10.1371/journal.pntd.0001798

39. Rai AK, Thakur CP, Singh A, Seth T, Srivastava SK, Singh P, et al. Regulatory $T$ cells suppress $\mathrm{T}$ cell activation at the pathologic site of human visceral leishmaniasis. PLoS One (2012) 7(2):e31551. doi:10.1371/journal.pone.0031551

40. Tang Q, Boden EK, Henriksen KJ, Bour-Jordan H, Bi M, Bluestone JA. Distinct roles of CTLA-4 and TGF-beta in CD4+CD25+ regulatory T cell function. Eur J Immunol (2004) 34(11):2996-3005. doi:10.1002/eji.200425143

41. Tai X, Cowan M, Feigenbaum L, Singer A. CD28 costimulation of developing thymocytes induces Foxp3 expression and regulatory $\mathrm{T}$ cell differentiation independently of interleukin 2. Nat Immunol (2005) 6(2):152-62. doi:10.1038/ ni1160

42. Keir ME, Butte MJ, Freeman GJ, Sharpe AH. PD-1 and its ligands in tolerance and immunity. Annu Rev Immunol (2008) 26:677-704. doi:10.1146/annurev. immunol.26.021607.090331

43. Esch KJ, Juelsgaard R, Martinez PA, Jones DE, Petersen CA. Programmed death 1-mediated $\mathrm{T}$ cell exhaustion during visceral leishmaniasis impairs phagocyte function. J Immunol (2013) 191(11):5542-50. doi:10.4049/jimmunol. 1301810

44. Butte MJ, Keir ME, Phamduy TB, Sharpe AH, Freeman GJ. Programmed death-1 ligand 1 interacts specifically with the B7-1 costimulatory molecule to inhibit T cell responses. Immunity (2007) 27(1):111-22. doi:10.1016/j. immuni.2007.05.016

45. Joshi T, Rodriguez S, Perovic V, Cockburn IA, Stager S. B7-H1 blockade increases survival of dysfunctional CD8(+) T cells and confers protection against Leishmania donovani infections. PLoS Pathog (2009) 5(5):e1000431. doi:10.1371/journal.ppat.1000431

46. Vallejo A, Abad-Fernandez M, Moreno S, Moreno A, Perez-Elias MJ, Dronda F, et al. High levels of CD4(+) CTLA-4(+) Treg cells and CCR5 density in 
HIV-1-infected patients with visceral leishmaniasis. Eur J Clin Microbiol Infect Dis (2015) 34(2):267-75. doi:10.1007/s10096-014-2229-1

47. Melby PC, Tabares A, Restrepo BI, Cardona AE, McGuff HS, Teale JM. Leishmania donovani: evolution and architecture of the splenic cellular immune response related to control of infection. Exp Parasitol (2001) 99(1):17-25. doi:10.1006/expr.2001.4640

48. Murray HW. Tissue granuloma structure-function in experimental visceral leishmaniasis. Int JExp Pathol (2001) 82(5):249-67. doi:10.1046/j.1365-2613.2001.00199.x

49. Melo FA, Moura EP, Ribeiro RR, Alves CF, Caliari MV, Tafuri WL, et al. Hepatic extracellular matrix alterations in dogs naturally infected with Leishmania (Leishmania) chagasi. Int J Exp Pathol (2009) 90(5):538-48. doi:10.1111/j.1365-2613.2009.00681.x

50. Sanchez MA, Diaz NL, Zerpa O, Negron E, Convit J, Tapia FJ. Organ-specific immunity in canine visceral leishmaniasis: analysis of symptomatic and asymptomatic dogs naturally infected with Leishmania chagasi. Am J Trop Med Hyg (2004) 70(6):618-24.

51. Beattie L, Peltan A, Maroof A, Kirby A, Brown N, Coles M, et al. Dynamic imaging of experimental Leishmania donovani-induced hepatic granulomas detects Kupffer cell-restricted antigen presentation to antigen-specific CD8 T cells. PLoS Pathog (2010) 6(3):e1000805. doi:10.1371/journal.ppat.1000805

52. Costa AS, Costa GC, Aquino DM, Mendonca VR, Barral A, Barral-Netto M, et al. Cytokines and visceral leishmaniasis: a comparison of plasma cytokine profiles between the clinical forms of visceral leishmaniasis. Mem Inst Oswaldo Cruz (2012) 107(6):735-9. doi:10.1590/S0074-02762012000600005

53. Beattie L, Phillips R, Brown N, Owens BM, Chauhan N, Dalton JE, et al. Interferon regulatory factor 7 contributes to the control of Leishmania donovani in the mouse liver. Infect Immun (2011) 79(3):1057-66. doi:10.1128/ IAI.00633-10

54. Stanley AC, Zhou Y, Amante FH, Randall LM, Haque A, Pellicci DG, et al. Activation of invariant NKT cells exacerbates experimental visceral leishmaniasis. PLoS Pathog (2008) 4(2):e1000028. doi:10.1371/journal.ppat.1000028

55. Beattie L, Svensson M, Bune A, Brown N, Maroof A, Zubairi S, et al. Leishmania donovani-induced expression of signal regulatory protein alpha on Kupffer cells enhances hepatic invariant NKT-cell activation. Eur J Immunol (2010) 40(1):117-23. doi:10.1002/eji.200939863

56. Maroof A, Beattie L, Zubairi S, Svensson M, Stager S, Kaye PM. Posttranscriptional regulation of II10 gene expression allows natural killer cells to express immunoregulatory function. Immunity (2008) 29(2):295-305. doi:10.1016/j.immuni.2008.06.012

57. Beattie L, d'El-Rei Hermida M, Moore JW, Maroof A, Brown N, Lagos D, et al. A transcriptomic network identified in uninfected macrophages responding to inflammation controls intracellular pathogen survival. Cell Host Microbe (2013) 14(3):357-68. doi:10.1016/j.chom.2013.08.004

58. Khadem F, Gao X, Mou Z, Jia P, Movassagh H, Onyilagha C, et al. Hepatic stellate cells regulate liver immunity to visceral leishmaniasis through P110delta-dependent induction and expansion of regulatory $\mathrm{T}$ cells in mice. Hepatology (2015) 63: 620-32. doi:10.1002/hep.28130

59. Al-Saffar NR, Al-Mudhaffer SA. Lactate dehydrogenase and other enzymes in kala-azar patients in Iraq. Indian J Med Res (1979) 70:598-608.

60. Tonin AA, Calado AM, Bottari NB, Dalenogare D, Thome GR, Duarte T, et al. Novel markers of inflammatory response and hepatic dysfunction in canine leishmaniasis. Comp Immunol Microbiol Infect Dis (2015) 44: 61-4. doi:10.1016/j.cimid.2015.09.004

61. el Hag IA, Hashim FA, el Toum IA, Homeida M, el Kalifa M, el Hassan AM. Liver morphology and function in visceral leishmaniasis (Kala-azar). J Clin Pathol (1994) 47(6):547-51. doi:10.1136/jcp.47.6.547

62. Tennent DM, Zanetti ME, Atkinson DI, Kuron GW, Opdyke DF. The endogenous origin of blood cholesterol. J Biol Chem (1957) 228(1):241-5.

63. Ghosh J, Lal CS, Pandey K, Das VN, Das P, Roychoudhury K, et al. Human visceral leishmaniasis: decrease in serum cholesterol as a function of splenic parasite load. Ann Trop Med Parasitol (2011) 105(3):267-71. doi:10.1179/136 485911X12899838683566

64. Carvalho MD, Alonso DP, Vendrame CM, Costa DL, Costa CH, Werneck GL, et al. Lipoprotein lipase and PPAR alpha gene polymorphisms, increased very-low-density lipoprotein levels, and decreased high-density lipoprotein levels as risk markers for the development of visceral leishmaniasis by
Leishmania infantum. Mediators Inflamm (2014) 2014:230129. doi:10.1155/ 2014/230129

65. Ghosh J, Bose M, Roy S, Bhattacharyya SN. Leishmania donovani targets Dicer1 to downregulate miR-122, lower serum cholesterol, and facilitate murine liver infection. Cell Host Microbe (2013) 13(3):277-88. doi:10.1016/j. chom.2013.02.005

66. Cavalcanti AS, Ribeiro-Alves M, Pereira Lde O, Mestre GL, Ferreira AB, Morgado FN, et al. Parasite load induces progressive spleen architecture breakage and impairs cytokine mRNA expression in Leishmania infantum-naturally infected dogs. PLoS One (2015) 10(4):e0123009. doi:10.1371/journal. pone.0123009

67. Dos-Santos WL, Pagliari C, Santos LG, Almeida VA, e Silva TL, Coutinho Jde J Jr, et al. A case of conventional treatment failure in visceral leishmaniasis: leukocyte distribution and cytokine expression in splenic compartments. BMC Infect Dis (2014) 14:491. doi:10.1186/ 1471-2334-14-491

68. Santana CC, Vassallo J, de Freitas LA, Oliveira GG, Pontes-de-Carvalho LC, dos-Santos WL. Inflammation and structural changes of splenic lymphoid tissue in visceral leishmaniasis: a study on naturally infected dogs. Parasite Immunol (2008) 30(10):515-24. doi:10.1111/j.1365-3024. 2008.01051.x

69. Bronte V, Pittet MJ. The spleen in local and systemic regulation of immunity. Immunity (2013) 39(5):806-18. doi:10.1016/j.immuni.2013.10.010

70. Yurdakul P, Dalton J, Beattie L, Brown N, Erguven S, Maroof A, et al. Compartment-specific remodeling of splenic micro-architecture during experimental visceral leishmaniasis. Am J Pathol (2011) 179(1):23-9. doi:10.1016/j.ajpath.2011.03.009

71. Dalton JE, Glover AC, Hoodless L, Lim EK, Beattie L, Kirby A, et al. The neurotrophic receptor Ntrk2 directs lymphoid tissue neovascularization during Leishmania donovani infection. PLoS Pathog (2015) 11(2):e1004681. doi:10.1371/journal.ppat.1004681

72. Dalton JE, Kaye PM. Immunomodulators: use in combined therapy against leishmaniasis. Expert Rev Anti Infect Ther (2010) 8(7):739-42. doi:10.1586/ eri.10.64

73. Ato M, Stager S, Engwerda CR, Kaye PM. Defective CCR7 expression on dendritic cells contributes to the development of visceral leishmaniasis. Nat Immunol (2002) 3(12):1185-91. doi:10.1038/ni861

74. Smelt SC, Engwerda CR, McCrossen M, Kaye PM. Destruction of follicular dendritic cells during chronic visceral leishmaniasis. JImmunol (1997) 158(8):3813-21.

75. Dalton JE, Maroof A, Owens BM, Narang P, Johnson K, Brown N, et al. Inhibition of receptor tyrosine kinases restores immunocompetence and improves immune-dependent chemotherapy against experimental leishmaniasis in mice. J Clin Invest (2010) 120(4):1204-16. doi:10.1172/JCI41281

76. Varma N, Naseem S. Hematologic changes in visceral leishmaniasis/kala azar. Indian J Hematol Blood Transfus (2010) 26(3):78-82. doi:10.1007/ s12288-010-0027-1

77. Faleiro RJ, Kumar R, Hafner LM, Engwerda CR. Immune regulation during chronic visceral leishmaniasis. PLoS Negl Trop Dis (2014) 8(7):e2914. doi:10.1371/journal.pntd.0002914

78. Marwaha N, Sarode R, Gupta RK, Garewal G, Dash S. Clinico-hematological characteristics in patients with kala azar. A study from north-west India. Trop Geogr Med (1991) 43(4):357-62.

79. Calvo JM, Hernandez JM, Palencia J, Sierra E. [Visceral leishmaniasis presenting with peripheral leukocytosis and lymphocytosis]. Sangre (Barc) (1994) 39(1):57-8.

80. Lafuse WP, Story R, Mahylis J, Gupta G, Varikuti S, Steinkamp H, et al. Leishmania donovani infection induces anemia in hamsters by differentially altering erythropoiesis in bone marrow and spleen. PLoS One (2013) 8(3):e59509. doi:10.1371/journal.pone.0059509

81. Cotterell SE, Engwerda CR, Kaye PM. Enhanced hematopoietic activity accompanies parasite expansion in the spleen and bone marrow of mice infected with Leishmania donovani. Infect Immun (2000) 68(4):1840-8. doi:10.1128/IAI.68.4.1840-1848.2000

82. Cotterell SE, Engwerda CR, Kaye PM. Leishmania donovani infection of bone marrow stromal macrophages selectively enhances myelopoiesis, by a mechanism involving GM-CSF and TNF-alpha. Blood (2000) 95(5):1642-51. 
83. Singal P, Singh PP. Leishmania donovani amastigote components-induced colony-stimulating factors production. Parasitol Int (2005) 54(1):9-20. doi:10.1016/j.parint.2004.08.001

84. Sibley LD. Invasion and intracellular survival by protozoan parasites. Immunol $\operatorname{Rev}(2011)$ 240(1):72-91. doi:10.1111/j.1600-065X.2010.00990.x

85. Dutra RA, Dutra LF, Reis Mde O, Lambert RC. Splenectomy in a patient with treatment-resistant visceral leishmaniasis: a case report. Rev Soc Bras Med Trop (2012) 45(1):130-1. doi:10.1590/S0037-86822012000100027

86. Flower DR, Macdonald IK, Ramakrishnan K, Davies MN, Doytchinova IA. Computer aided selection of candidate vaccine antigens. Immunome Res (2010) 6(Suppl 2):S1. doi:10.1186/1745-7580-6-S2-S1

87. Albergante L, Timmis J, Beattie L, Kaye PM. A Petri net model of granulomatous inflammation: implications for IL-10 mediated control of Leishmania donovani infection. PLoS Comput Biol (2013) 9(11):e1003334. doi:10.1371/ journal.pcbi.1003334
88. Blohmke CJ, O'Connor D, Pollard AJ. The use of systems biology and immunological big data to guide vaccine development. Genome Med (2015) 7(1):114. doi:10.1186/s13073-015-0236-1

Conflict of Interest Statement: The authors declare that the research was conducted in the absence of any commercial or financial relationships that could be construed as a potential conflict of interest.

Copyright (c) 2016 de Freitas, Leoratti, Freire-de-Lima, Morrot and Feijó. This is an open-access article distributed under the terms of the Creative Commons Attribution License (CC BY). The use, distribution or reproduction in other forums is permitted, provided the original author(s) or licensor are credited and that the original publication in this journal is cited, in accordance with accepted academic practice. No use, distribution or reproduction is permitted which does not comply with these terms. 